\title{
Physic nut plants present high mycorrhizal dependency under conditions of low phosphate availability
}

\section{Elcio Liborio Balota ${ }^{1 *}$, Oswaldo Machineski ${ }^{1}$, Priscila Viviane Truber ${ }^{1}$, Alexandra Scherer ${ }^{1}$ and Fabio Suano de Souza ${ }^{2}$}

${ }^{1}$ Soil Science Department, Agricultural Research Institute of Paraná (IAPAR), Caixa Postal 481, 86001-970 Londrina, Paraná, Brasil.

${ }^{2}$ Ecophysiology Department, IAPAR, Londrina, Paraná. Now at the Agronomy College, Filadelfia University (UNIFIL), Londrina, Paraná, Brasil.

* Corresponding author: balota@iapar.br

Received: 18 November 2010; Accepted: 01 February 2011.

\section{ABSTRACT}

The physic nut (Jatropha curcas L.) is a perennial tree that occurs naturally in the tropical and subtropical regions of Brazil. Fruits of physic nut present an oil content of $28 \%$ on a dry weight basis. Although the plant has adapted to diverse soil conditions such as low fertility, the correction of soil acidity and the addition of fertilizer are essential for highly productive plants. Thus, the response of the physic nut to different soil phosphorus levels (P) and arbuscular mycorrhizal fungi (AMF) inoculation must be characterized. Hence, the objective of the present study was to evaluate the response of physic nut seedlings to arbuscular mycorrhizal fungi (AMF) inoculation at different levels of soil P. Experiment was carried out in a greenhouse encompassing AMF treatments (inoculation with Gigaspora margarita or Glomus clarum, and the non inoculated controls), and phosphorus treatments $(0,25,50,100,200$ and 400 $\mathrm{mg} \mathrm{kg}^{-1}$ added to soil). At low soil P levels, arbuscular mycorrhizal fungi inoculation had a significant positive effect on plant growth, shoot and root dry matter content, plant height, number of leaves, total leaf area, leaf area per leaf and the Dickson quality index. The root:shoot ratio and the leaf area ratio were also affected by mycorrhizal inoculation and the level of $\mathrm{P}$ addition. Physic nut plants exhibited high mycorrhizal dependency at soil $P$ additions up to $50 \mathrm{mg} \mathrm{kg}^{-1}$.

Key words: mycorrhizal inoculation, plant growth, leaf area, biomass dry matter.

\section{RESUMO}

0 pinhão manso (Jatropha curcas L.) é uma planta perene que pode ser encontrada naturalmente em regiões tropicais e subtropicais do Brasil. Seus frutos apresentam $28 \%$ de óleo com base no peso seco. Apesar de o pinhão manso apresentar alta adaptabilidade às diversas condições do solo como baixa fertilidade, a correção da acidez do solo e a adição de fertilizantes são fundamentais para a alta produtividade das plantas. Por isto é essencial avaliar o comportamento do pinhão manso em diferentes níveis de $\mathrm{P} \mathrm{e}$ sua resposta a inoculação dos fungos micorrízicos arbusculares (FMA). 0 objetivo do trabalho foi 0 de avaliar 0 efeito dos fungos micorrízicos arbusculares em mudas de pinhão manso em diferentes doses de $\mathrm{P}$ no solo. Foi conduzido um experimento em casa de vegetação, com tratamentos de fungos micorrízicos (Controle, Gigaspora margarita e Glomus clarum) e de adição de $\mathrm{P}(0,25$, 50, 100, 200 e $400 \mathrm{mg} \mathrm{kg} \mathrm{solo}^{-1}$ ). Houve efeito benéfico significativo dos fungos micorrízicos arbusculares no desenvolvimento 
vegetativo como: peso da matéria seca da parte aérea e das raízes, altura, diâmetro do caule, número de folhas, área foliar, área foliar por folha e índice de qualidade Dickson, principalmente nas doses menores de P. A relação raiz:parte aérea e relação da área foliar foram influenciadas pela micorrização e pelos teores de $\mathrm{P}$ no solo. 0 pinhão manso apresentou alta dependência micorrízica até a dose de $50 \mathrm{mg} \mathrm{kg}^{-1}$ de P.

Palavras-chaves: inoculação de micorrizas, desenvolvimento da planta, área foliar, matéria seca da biomassa.

\section{INTRODUCTION}

The physic nut (Jatropha curcas L.) is a perennial plant that belongs to the Euphorbiaceae family and is native to Central America. Nevertheless, it occurs naturally in the tropical and subtropical regions of Brazil (Beltrão, 2005). This plant is a bush or tree of rapid growth rates and that can reach over $5 \mathrm{~m}$ in height. The fruits contain an oil content of $28 \%$ on a dry basis, of which $39 \%$ is obtained from the seed, and 61\% from the albumen (Saturino et al., 2005; Dias et al., 2007).

Due to the high oil content of the fruit, physic nuts have great potential for use as an alternative crop for biodiesel production. The physic nut plant produces 2 to $4 \mathrm{~kg}$ of seeds per plant in the fourth year of cultivation (Tominaga, 2007), maintaining high production rates for more than 40 years. Depending on the spacing of the trees, productivity rates greater than $6,000 \mathrm{~kg} \mathrm{ha}^{-1}$ of seeds can be obtained, and over $2,000 \mathrm{~kg} \mathrm{ha}^{-1}$ of oil can be produced. However, it is estimated that breeding programs and optimal crop management practices, could improve the yield potential to more than $4,000 \mathrm{~kg} \mathrm{ha}^{-1}$ of oil (Laviola and Dias, 2008).

The interest in the physic nut has increased rapidly due to its high oil content, which is fundamental for the economical viability of biofuel production. Biofuel is an important source of renewable energy and can be used to offset the environmental impact of fossil fuel combustion. Thus, the physic nut has been increasingly cultivated in Africa and India for biodiesel production (Núñez-Colín and Goytia-Jiménez, 2009).

Due to the potential of the physic nut as a raw material for the production of biofuel, the demand for physiological and agronomical information on this species, including the nutritional requirements, have increased dramatically. The physic nut is considered a rustic crop that can grow in diverse soils and climatic conditions, including low fertility environments (Saturnino et al., 2005; Dias et al., 2007).
However, to obtain high fruit production rates, the plant requires fertile soils with good physical characteristics. Thus, the correction of soil acidity and the addition of fertilizers are essential for successful physic nut crop production.

To enhance physic nut fruit production, its response to arbuscular mycorrhizal fungi (AMF) inoculation and different levels of $P$ in the soil must be determined. AMF are of great ecological importance because they can form a symbiosis with the roots of more than $90 \%$ of all terrestrial plants contributing to their nutritional requirements and development. The extensive extraradical hyphae network produced by the AMF increases the effective absorptive area of the roots by more than a hundred times the area of soil exploration, which enhances the efficiency of nutrient absorption. For instance, mycorrhizal association is responsible for up to $80 \%$ of the total $\mathrm{P}$ uptake by plants (Marschner and Dell, 1994). One of the strongest effects of AMF inoculation is an increase in the development of the host plant, which is attributed to an increase in nutrient uptake, particularly those that have low soil mobility and low concentration in the soil solution. Symbiosis is characterized by the bi-directional movement of nutrients, in which the fungi help the plants uptake nutrients from the soil, and the plant provides sugars to the fungi. Moreover, mycorrhizal symbioses can enhance disease resistance and alleviate cultural and environmental stress (Smith and Read, 1997).

Mycorrhizal symbiosis plays an important role in tropical regions because the adsorption capacity of tropical soils is high and the nutrient content of the source material is low (Novais and Smyth, 1999). Thus, under low soil $P$ conditions, phosphate fertilization is essential for the establishment of crops.

Crops that are produced in the nursery and are transplanted to the field can present variable degrees of plant stress. In this context, AMF inoculation has been proved to be an important practice for transplanted crops because AMF may reduce the required amount of fertilizer, improve 
development and the nutritional status of the plants, reduce transplant time and increase the survival rate of seedlings in the field (Saggin Júnior and Siqueira, 1996). However, there are few studies on the effect of AMF on physic nuts grown under different soil P levels (Carvalho, 2008).

The objective of the present study was to evaluate the effect of arbuscular mycorrhizal fungi on the development of physic nut seedlings grown under different soil P levels.

\section{MATERIAL AND METHODS}

The experiment was conducted in a greenhouse using pots containing $4 \mathrm{~kg}$ of sandy soil. An Oxisol soil classified as a dystrophic Red Latosol was used as substrate, and it presented the following chemical characteristics: $\mathrm{pH}$ in $\mathrm{CaCl}_{2}=4.1 ; \mathrm{P}$ in Mehlich solution $=2.3 \mathrm{mg} \mathrm{kg}^{-1}$; organic $C$ content $=12.9 \mathrm{~g} \mathrm{dm}^{-3}$. Dolomitic limestone was added to the soil to attain $70 \%$ cation base saturation in the CEC, and it was incubated for 60 days at field conditions. After incubation, the $\mathrm{pH}$ of the soil was equal to 6.4 , and the $\mathrm{P}$ content was $7.8 \mathrm{mg} \mathrm{kg}^{-1}$. The substrate was autoclaved twice at $121^{\circ} \mathrm{C}$ for one hour. After 20 days, the substrate was fertilized with triple superphosphate.

The experiment was completely randomized in a factorial arrangement, and three AMF treatments (control without AMF inoculation and inoculation with Gigaspora margarita or Glomus clarum), six phosphorus treatments ( 0 , 25, 50, 100, 200 and $400 \mathrm{mg} \mathrm{kg} \mathrm{soil}^{-1}$ ) and four replicates were evaluated. After the addition of 25, 50, 100, 200 and $400 \mathrm{mg} \mathrm{kg}^{-1}$ of $P$, the soil presented a $P$ content of 15,25 , 48, 101 and $221 \mathrm{mg} \mathrm{kg}^{-1}$, respectively. The $P$ treatments were denominated as P0, P25, P50, P100, P200 and P400, respectively.

Physic nut seeds were germinated in sterilized vermiculite, and the seedlings were transplanted when two leaves were observed. Approximately 120 AMF spores per pot were inoculated $5 \mathrm{~cm}$ below the roots of the selected seedlings. The mycorrhizal inoculum was obtained from the IAPAR (Agricultural Research Institute of Paraná) collection, which used Brachiaria decumbens as a host plant.

The experiment was conducted for 180 days, and the following parameters were evaluated: plant height, number of leaves per plant, total leaf area per plant, stem diameter and the dry matter and $\mathrm{P}$ content of the shoots and roots. At harvest, the leaf area was determined with an area meter (LI-3100C Area Meter), and the plant height was measured from the soil surface to the top of the main plant stem. The diameter of the stem was measured at the soil surface using a pachymeter. Photosynthetic gas exchange $\left(\mathrm{CO}_{2}\right)$ was determined between 10 and $11 \mathrm{a} . \mathrm{m}$. on the $150^{\text {th }}$ day of the experiment under saturated light conditions, and the measurements were conducted with a portable photosynthesis system (LI-COR, LI-6200 model) and an infra red gas analyzer (IRGA). Three plants per treatment were selected, and the photosynthetic measurements were performed on an intact, totally expanded leaf located in the middle of the seedling. The leaf used in the photosynthetic measurements did not display any signs of disease or senescence. All of the soil analyses were performed according to the Soil and Plant Analyses of the IAPAR (Pavan et al., 1992).

The Dickson Quality Index (DQI) was calculated according to the following formula (Dickson et al., 1960): $\mathrm{DQI}=(\mathrm{TDM}) /(\mathrm{PH} / \mathrm{SD}+\mathrm{SDM} / \mathrm{RDM})$, where TDM is the total dry matter, $\mathrm{PH}$ is the plant height, $\mathrm{SD}$ is the stem diameter, SDM is the shoot dry matter content and RDM is the root dry matter content. The relative mycorrhizal dependency (RDM) was calculated based on the dry matter content of the shoot or the root (RDM = (dry matter of mycorrhizal plant - dry matter of non-mycorrhizal plant)/dry matter of mycorrhizal plant $x$ 100).

The results were submitted to an analysis of variance (ANOVA test), and AMF inoculation and $\mathrm{P}$ addition were evaluated. The significance of treatment effects were assessed by analysis of variance and the means compared at a confidence level of $\mathrm{P} \leq 0.05$ by performing a Tukey's test. A polynomial regression model was applied, and Pearson correlation coefficients between variables were calculated. All of the statistical analyses were performed using version 9 of SAS statistical software (SAS, 2002).

\section{RESULTS}

Mycorrhizal plants exhibited interactive effects between AMF inoculation and $\mathrm{P}$ dose, and a polynomial regression model provided a satisfactory fit of the relationship between the $\mathrm{P}$ addition and most of the variables tested (Figures 
1 to 5). In general, mycorrhizal plants presented greater development than non-mycorrhizal plants at low $\mathrm{P}$ levels. However, the beneficial effects of mycorrhizal inoculation decreased with an increase in the $P$ level. Significant differences in the plant growth and Dickson quality index were not observed between the two AMF species.

Plant height and stem diameter: Physic nut height and stem diameter increased with the increase in $P$ addition, and the relationship between the soil $P$ level and the physic nut height and stem diameter followed a second degree polynomial model. Mycorrhizal plants presented greater heights and stem diameters than non-mycorrhizal plants at low P levels. AMF inoculation increased the plant height by $106 \%, 96 \%, 99 \%$ and $52 \%$ at P levels of P0, P25, P50 and P100, respectively (Figure $1 \mathrm{~A})$. Moreover, the stem diameter of inoculated plants was $44 \%$ greater than that of soil without $P$ additions (Figure 1B).
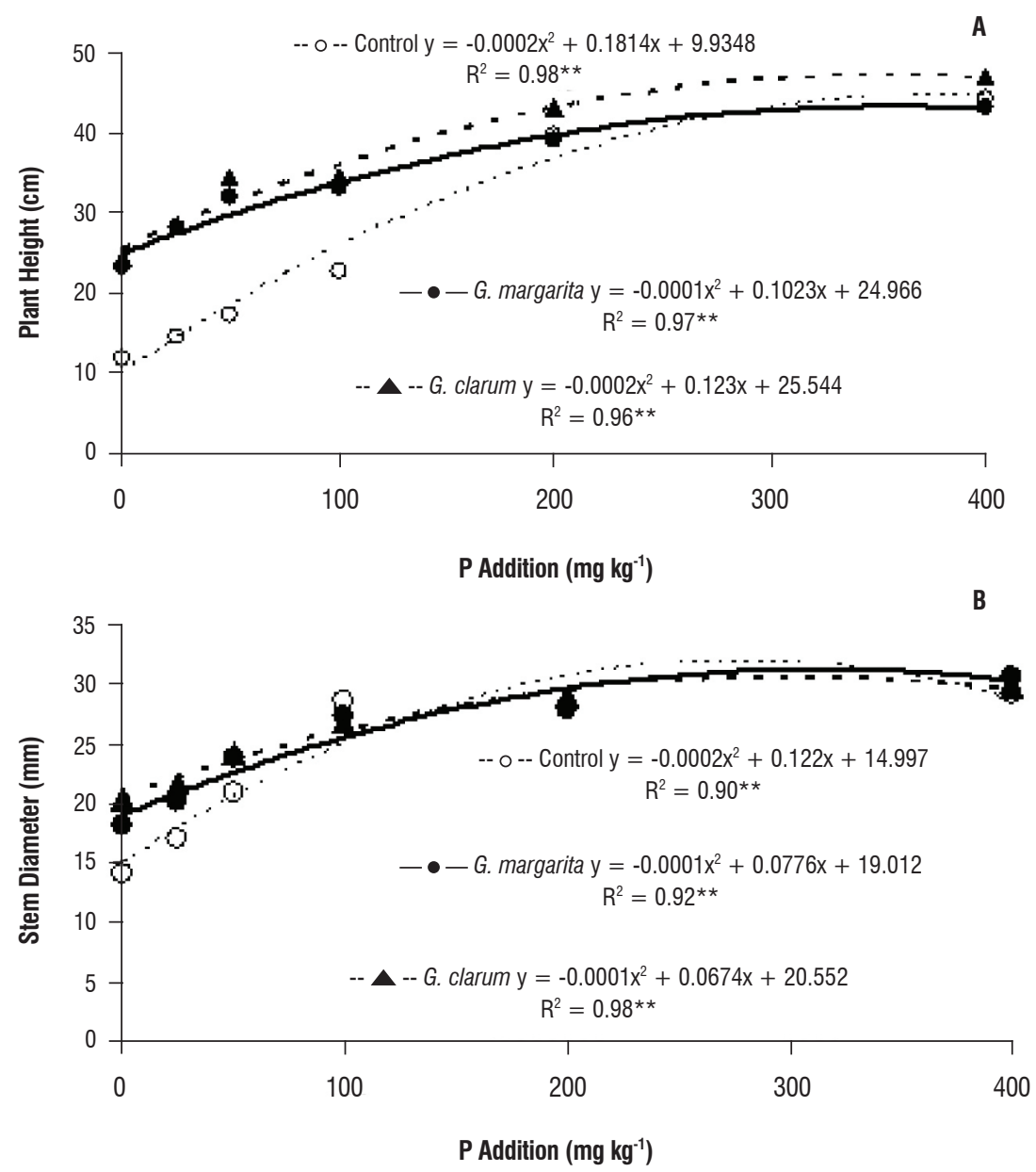

Figure 1. Plant height $(A)$ and stem diameter (B) of physic nut plants due to the inoculation of arbuscular mycorrhizal fungi at different $P$ levels. ** Significant at a $1 \%$ probability level, according to $\mathrm{F}$ test results. 
Shoot and root dry matter: Mycorrhizal plants presented greater shoot dry matter (SDM) and root dry matter contents (RDM) than non-mycorrhizal plants at all P levels, and a second degree polynomial regression model fit the relationship between the $\mathrm{P}$ concentration and the SDM and RDM content (Figure 2). At P levels of P0, P25 and P50, AMF inoculation increased the SDM content by $571 \%, 223 \%$ and $195 \%$, respectively. Moreover, in P0, P25 and P50, AMF inoculation increased the RDM by $392 \%, 176 \%$ and $287 \%$, respectively.

The root:shoot ratio increased with the increase in $\mathrm{P}$ addition, and a second degree polynomial regression model was applicable to the results of $G$. margarita inoculations as well as for the control. Alternatively, a linear regression model best fit the results obtained from $G$. clarum inoculations (Figure $2 \mathrm{C}$ ). In general, the root:shoot ratio of non-mycorrhizal plants increased with the increase in $\mathrm{P}$ addition; however, when low P levels were applied (up to P50), a linear decrease in the root:shoot ratio was observed $\left(r^{2}=0.99\right)$, while in high $\mathrm{P}$ levels (above P50), the root:shoot ratio followed a positive polynomial regression model $\left(r^{2}=0.96\right)$

Number of leaves: The number of leaves increased with the increase in $\mathrm{P}$ addition. As the $\mathrm{P}$ level increased, the control (without AMF treatment) and G. margarita inoculations presented a second degree polynomial model, whereas data from G. clarum inoculations followed a linear regression model (Figure 3A). Mycorrhizal plants produced a greater number of leaves than non-mycorrhizal plants regardless the $P$ treatment. Namely, AMF inoculation increased the number of leaves by $242 \%$ in $\mathrm{P} 0,143 \%$ in $\mathrm{P} 25,124 \%$ in $\mathrm{P} 50$ and $44 \%$ in $\mathrm{P} 100$.

Leaf area: As the P soil content increased to $200 \mathrm{mg}$ $\mathrm{kg}^{-1}$, the total leaf area per plant and the leaf area per leaf also increased, following a second degree polynomial regression model. Mycorrhizal plants presented greater leaf areas per plant and per leaf than non-mycorrhizal plants at $P$ additions less than $100 \mathrm{mg} \mathrm{kg}^{-1}$. AMF inoculation significantly increased the total leaf area per plant by $826 \%$ in P0, $391 \%$ in $\mathrm{P} 25,230 \%$ in $\mathrm{P} 50$ and $81 \%$ in $\mathrm{P} 100$ (Figure 3B), while the leaf area per leaf increased by $171 \%$ in P0, 101\% in P25 and $47 \%$ in P50 (Figure 3C).
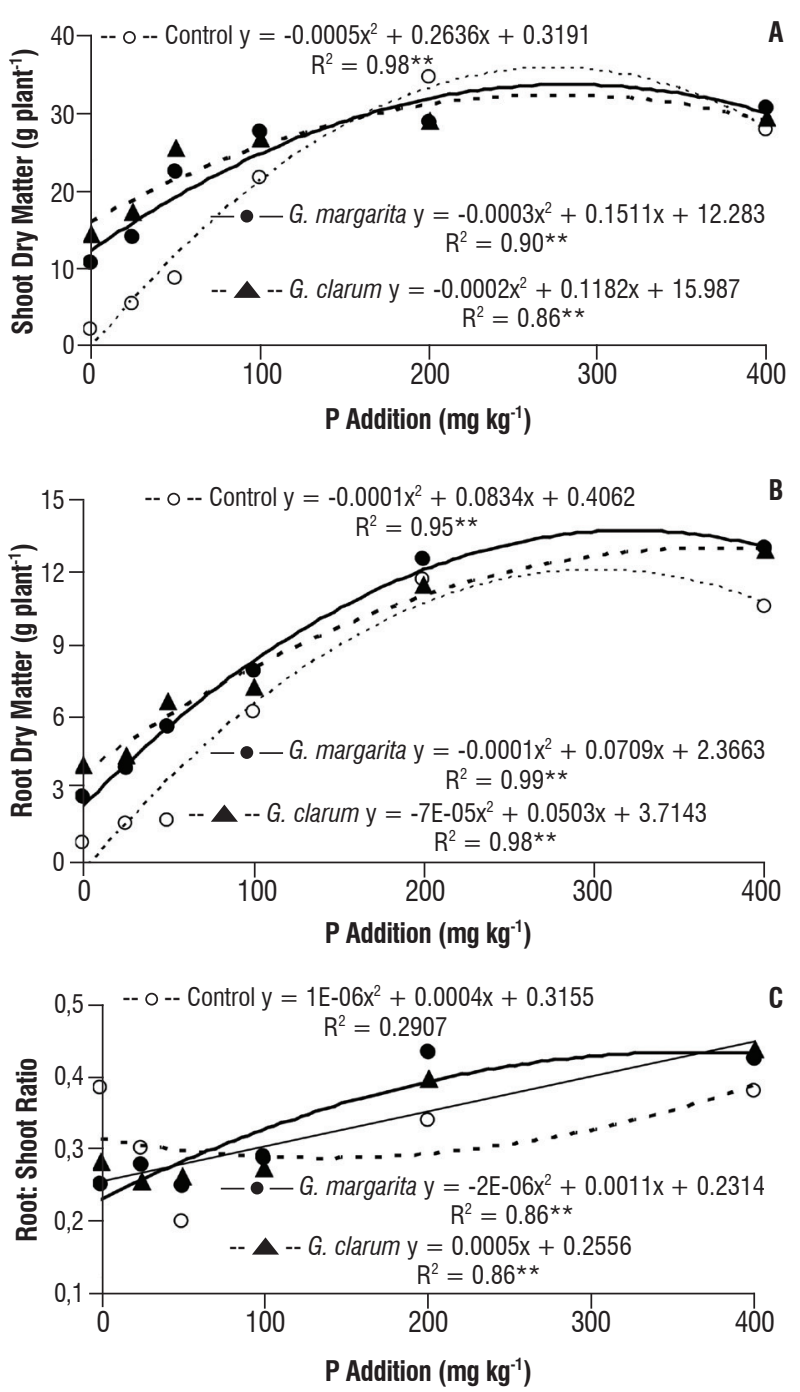

Figure 2. Shoot (A) and root (B) dry matter and root:shoot ratio (C) of physic nut plants due to the inoculation of arbuscular mycorrhizal fungi at different P levels. * and ** Significant at a $5 \%$ and $1 \%$ probability level, respectively, according to $\mathrm{F}$ test results.

Leaf area ratio: Leaf area ratio (LAR) decreased with the increase in $\mathrm{P}$ addition, and the relationship between the leaf area ratio of mycorrhizal plants and the $P$ soil content followed a second degree polynomial model. At the P0 and P25 treatments, the LAR of mycorrhizal plants was $57 \%$ and $61 \%$ greater than that of non-mycorrhizal plants, respectively (Figure 3D). The LAR describes the relationship between the total leaf area and total plant dry matter content. 

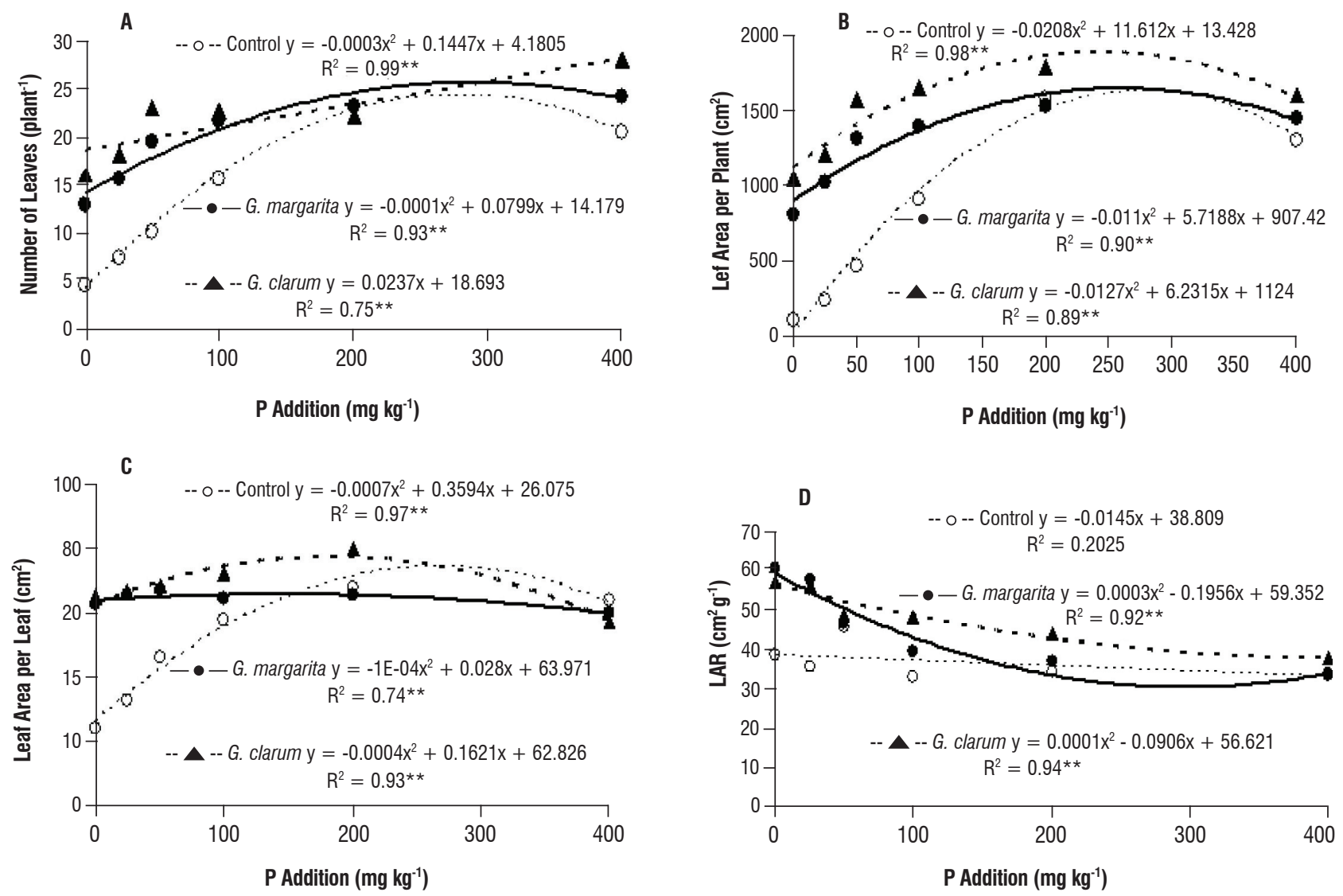

Figure 3. Number of leaves $(A)$, leaf area per plant $(B)$, leaf area per leaf $(C)$ and leaf area ratio-LAR (D) of physic nut plants due to the inoculation of arbuscular mycorrhizal fungi at different $\mathrm{P}$ levels. * and ${ }^{* \star}$ Significant at a $5 \%$ and $1 \%$ probability level, respectively, according to $\mathrm{F}$ test results.

Photosynthesis rate: The rate of photosynthesis was improved due to the AMF inoculation regardless the P treatment. In mycorrhizal plants, photosynthesis increased up to $30 \%$ in P200 and P400 compared to non-mycorrhizal plants (Table 1).

Table 1. The rate of photosynthesis in physic nut plants due to the inoculation of arbuscular mycorrhizal fungi at different $P$ levels.

\begin{tabular}{cccc}
\hline \multirow{2}{*}{ P Addition $\left(\mathbf{m g ~ k g}^{-1}\right)$ ) } & \multicolumn{3}{c}{$\boldsymbol{\mu}$ moles $\mathbf{C O}_{2} \mathbf{~ m}^{-2} \mathbf{~ s}^{-1}$} \\
\cline { 2 - 4 } & Control & G. margarita & G. clarum \\
\hline 0 & $7.9 \mathrm{~A} \mathrm{~b}$ & $9.0 \mathrm{~A} \mathrm{~b}$ & $9.7 \mathrm{~A} \mathrm{a}$ \\
25 & $9.0 \mathrm{~A} \mathrm{ab}$ & $9.4 \mathrm{Ab}$ & $10.0 \mathrm{~A} \mathrm{a}$ \\
50 & $10.4 \mathrm{~A} \mathrm{a}$ & $11.8 \mathrm{~A} \mathrm{ab}$ & $10.0 \mathrm{~A} \mathrm{a}$ \\
100 & $10.3 \mathrm{~A} \mathrm{a}$ & $12.9 \mathrm{~A} \mathrm{a}$ & $10.8 \mathrm{~A} \mathrm{a}$ \\
200 & $10.5 \mathrm{~B} \mathrm{a}$ & $13.5 \mathrm{~A} \mathrm{a}$ & $12.4 \mathrm{~A} \mathrm{a}$ \\
400 & $10.0 \mathrm{~B} \mathrm{a}$ & $13.0 \mathrm{~A} \mathrm{a}$ & $12.0 \mathrm{~A} \mathrm{a}$ \\
\hline
\end{tabular}

Means followed by a different upper case letter between column and lower case letter within column are significantly different by the Tukey test $(\mathrm{P} \leq 0.05)$.
$P$ accumulation: $P$ accumulation in the shoot and root increased with the increase in $\mathrm{P}$ addition. In the control plants, the relationship between the $P$ addition and $P$ accumulation fit a linear regression model. On the other hand, in the mycorrhizal treatments, $P$ accumulation followed a second degree polynomial model. Mycorrhizal plants presented greater $\mathrm{P}$ accumulation rates in the root and shoot than non-mycorrhizal plants at all $P$ levels. AMF inoculation increased $P$ accumulation in the shoot by $1542 \%$ in $\mathrm{P} 0,1018 \%$ in $\mathrm{P} 25,741 \%$ in $\mathrm{P} 50,250 \%$ in $\mathrm{P} 100$ and $50 \%$ in P200 (Figure 4A). Moreover, P accumulation in the root increased by $800 \%$ in $P 0,600 \%$ in P25, $1200 \%$ in P50 and $217 \%$ in P100 (Figure 4B). 

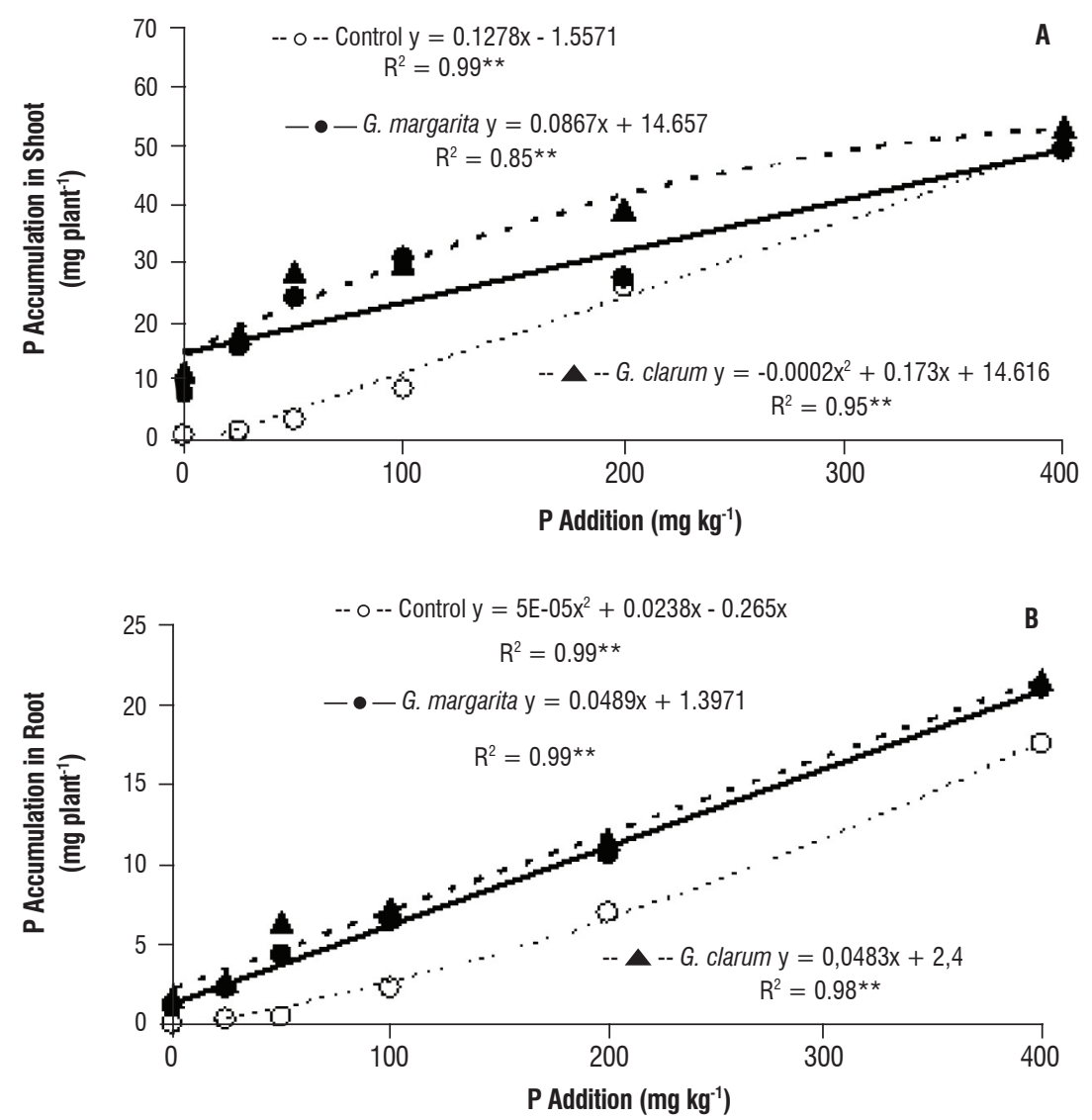

Figure 4. $\mathrm{P}$ accumulation in shoot $(\mathrm{A})$ and root $(\mathrm{B})$ of physic nut plants due to the inoculation of arbuscular mycorrhizal fungi at different $\mathrm{P}$ levels. ** Significant at a $1 \%$ probability level, according to $\mathrm{F}$ test results.

Dickson quality index: The value of the Dickson quality index (DQI) increased as the $P$ soil addition increased to $200 \mathrm{mg} \mathrm{kg}^{-1}$, and a second degree polynomial model was obtained. Mycorrhizal plants presented higher DQls than non- mycorrhizal plants at $P$ additions less than or equal to $50 \mathrm{mg}$ $\mathrm{kg}^{-1}$. AMF inoculation increased the DQI by $351 \%$ in P0, 150\% in P25 and $250 \%$ in P50 (Figure 5).

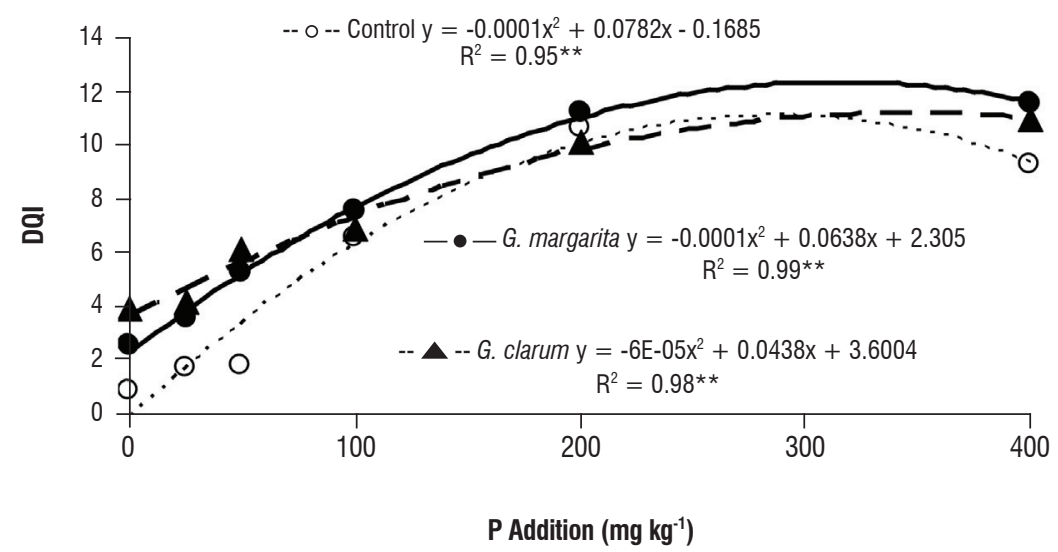

Figure 5. Dickson quality index (DQI) of physic nut plants due to the inoculation of arbuscular mycorrhizal fungi at different P levels. ** Significant at a $1 \%$ probability level, according to $\mathrm{F}$ test results. 
Relative mycorrhizal dependency: The relative mycorrhizal dependency (RMD) of the shoot and root dry matter contents compare the degree of responsiveness of mycorrhizal plants with non-mycorrhizal plants, which is dependent on the maximum development at a given soil fertility. Based on the shoot and root dry matter contents, the physic nut presented higher relative mycorrhizal dependency (RMD) at low $\mathrm{P}$ levels (Figure 6). However, mycorrhizal dependence decreased with the increase in the soil P content. The RDM was high in P0, P25 and P50, and the RMD was low in P100; thus, AMF inoculation has only a slight effect on plant development at high $\mathrm{P}$ levels. Significant differences in the RMD were not observed between the two AMF species tested. The observed decrease in the RMD with the increase in the soil P level suggests that mycorrhizal inoculation induce a beneficial effect mainly under low $P$ conditions.

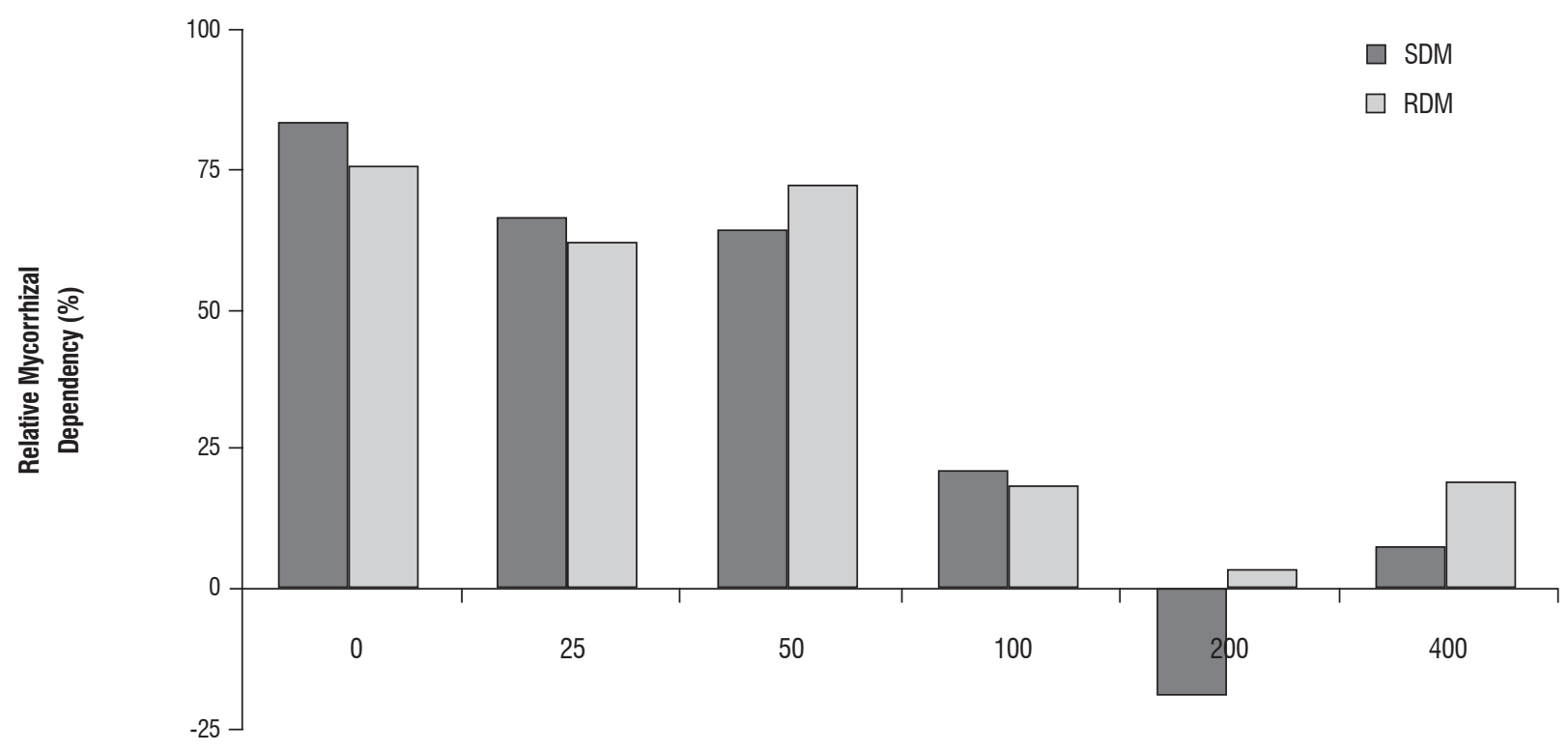

P Addition ( $\left.\mathrm{mg} \mathrm{kg}^{-1}\right)$

Figure 6. Relative mycorrhizal dependency. RMD = (dry matter of mycorrhizal plant) - (dry matter of non-mycorrhizal plant) / (dry matter of mycorrhizal plant) $\mathrm{x}$ 100. SDM: shoot dry matter; RDM: root dry matter.

\section{DISCUSSION}

The relationship between the $\mathrm{P}$ addition and the majority of variables fit a polynomial regression model, which suggests that mycorrhizal inoculation had a stronger effect at lower $\mathrm{P}$ levels (Saggin Júnior and Siqueira, 1996; Rocha et al, 2006). Mycorrhizal physic nut plants presented higher growth rates than non-mycorrhizal plants at low $\mathrm{P}$ doses. The beneficial effects of mycorrhizal inoculation on plant development can be quantified by calculating the dose of $P$ necessary to produce $60 \%$ of the maximum plant height. G. margarita inoculations provided $60 \%$ of the maximum physic nut plant height at a $\mathrm{P}$ addition of $30 \mathrm{mg} \mathrm{kg}^{-1}$. Alternatively, nonmycorrhizal plants presented an identical plant height when $\mathrm{P}$ addition of 120 of mg kg-1 was applied; thus, non-mycorrhizal plants required a dose that was four times greater than that of mycorrhizal plants to achieve the same height. Similar results were observed for the stem diameter, which is considered one of the most important indicators of the quality of seedlings (Gomes, 2001). Moreover, the stem diameter is related to the survival and growth of seedlings in the field.

The addition of $P$ increased the SDM and RDM of physic nut plants at low levels of $\mathrm{P}$ in mycorrhizal and nonmycorrhizal plants. The SDM and RDM of mycorrhizal plants increased by $571 \%$ and $392 \%$ compared to non-mycorrhizal plants, respectively. The values obtained in the present study were greater than those observed by Carvalho (2008), who demonstrated that mycorrhizal inoculation increased the SDM and RDM of physic nut plants by $79 \%$ and $146 \%$, 
respectively. In the present study, mycorrhizal inoculation had a stronger effect at lower $P$ levels, and the benefits of mycorrhizal inoculation decreased with an increase in the P addition. In the study conducted by Carvalho (2008), the benefits of mycorrhizal inoculation were greater at high $\mathrm{P}$ levels, and significant differences between mycorrhizal and non-mycorrhizal plants were not observed at low $P$ levels. However, the present study was conducted for 180 days, while the Carvalho (2008) study was conducted for 78 days.

The maximum effect of mycorrhizal inoculation on the SDM and RDM content was observed at 260 and $290 \mathrm{mg} \mathrm{kg}^{-1}$ of $P$ in the soil, respectively. At higher $P$ additions, a decrease in physic nut plant development was observed. When the $P$ addition was greater than $160 \mathrm{mg} \mathrm{kg}^{-1}$, mycorrhizal plants presented lower SDM values than non-mycorrhizal plants. On the other hand, the RDM of mycorrhizal plants was greater than that of non-mycorrhizal plants at all P treatments. Shoot development is often used as a parameter for the selection and classification of seedlings as it is related to the rusticity, survival and development under field conditions (Guimarães et al., 2010, Gomes and Paiva, 2004).

In mycorrhizal and non-mycorrhizal plants, the root:shoot ratio increased with the increase in the soil P. When 0 to $70 \mathrm{mg}$ $\mathrm{kg}^{-1}$ of $\mathrm{P}$ was added to the soil, mycorrhizal plants presented lower root:shoot ratios than non-mycorrhizal plants; however, at $P$ levels greater than $70 \mathrm{mg} \mathrm{kg}^{-1}$, mycorrhizal plants presented higher root:shoot ratios than non-mycorrhizal plants. In general, as the P concentration increased from the lowest to the highest level (P400), the root:shoot ratio of nonmycorrhizal plants and mycorrhizal plants increased by about $25 \%$ and $69 \%$, respectively. The root:shoot ratio describes the balance of water, nutrients and carbon in the plant, and is a useful index for identifying changes in the balance among plant organs due to environmental modifications.

In the present study, the root:shoot ratio of physic nut plants increased with the increase in the $\mathrm{P}$ addition; however, this result was not in agreement with those presented in the literature. The results of previous studies suggest that the typical response to $\mathrm{P}$ deficiency is an increase in the root:shoot ratio and preferential assimilation in the roots under low P conditions (Wissuwa et al., 2005). In general, when the supply of nutrients is low, fewer nutrients are available for shoot growth, and nutrients are used for root development. Alternatively, when the supply of nutrients is high, less root development and greater shoot growth are observed (Marschner et al., 1996). Thus, the plant aims to extract the maximum amount of available nutrients from the soil. This hypothesis is supported by the majority of the results presented in the literature, which suggest that the root:shoot ratio decreases with an increase in the $P$ level. However, previous studies on physic nut plants (Carvalho, 2008) and several forest tree species (Resende et al., 1999) indicate that the root:shoot ratio increases with the increase in $\mathrm{P}$ concentration. The results obtained by Carvalho (2008) revealed that the root:shoot ratio of the non-mycorrhizal and mycorrhizal physic nut plants increased by $19 \%$ and $93 \%$ as the P concentration increased from P10 to P110, respectively. The inverse relationship between the $P$ concentration and the root:shoot ratio may be due to sucrose inhibition in the chloroplasts and the accumulation of starch. Sucrose is the principal carbohydrate translocated from the shoot to the root; thus, if sucrose synthesis is inhibited at low P levels, the root:shoot ratio tends to increase (Carvalho, 2008). Resende et al. (1999) studied the development of forest tree seedlings with different physiological characteristics, and observed that the root:shoot ratio of several species decreased with the increase in $\mathrm{P}$ concentration, while the root:shoot ratio increased in other species (Schinus terebinthifolius, Mimosa caesalpiniaefolia and Sesbania virgata). According to Resende et al. (1999), the root:shoot ratio is dynamic and subject to diverse modifications, and determined by physiological differences among the plant organs. Although root and shoot development are directly related, the cause and results of this relationship remain unclear (Salisbury and Ross, 1992). Thus, the results of the present study are in agreement with previous observations on the physic nut plant and several forest tree species.

The root:shoot ratio is an important index for the evaluation of the quality of seedlings (Guimarães et al., 2010). A high root:shoot ratio is indicative of a more developed root system; thus, the root:shoot ratio can be used as an indicator of the rusticity of the plant. Moreover, because changes in the root system can alter the efficiency of the absorption of water and nutrients from the soil, especially those with low mobility, the root:shoot ratio is directly correlated to the initial growth and survival of seedlings in the field. However, the addition of $P$ had a significant effect on the root:shoot ratio; thus, partitioning in the physic nuts plants was affected by the $\mathrm{P}$ concentration. 
The addition of $\mathrm{P}$ also increased the number of leaves, total leaf per plant, leaf area per leaf and leaf area ratio (LAR) of mycorrhizal and non-mycorrhizal plants. When the plants were inoculated with $G$. clarum, the maximum total leaf area was obtained at a $\mathrm{P}$ addition of $200 \mathrm{mg} \mathrm{kg}^{-}$ 1. Alternatively, without AMF treatment, the maximum total leaf area was obtained at a $\mathrm{P}$ concentration of $250 \mathrm{mg} \mathrm{kg}^{-1}$. However, as the $\mathrm{P}$ concentration was further increased, a reduction in the total leaf area was observed. The efficiency of mycorrhizal symbiosis can be determined by calculating the $P$ addition necessary for the production of $70 \%$ of the maximum leaf area per plant. G. clarum provided $70 \%$ of the maximum leaf area per plant at a $\mathrm{P}$ addition of $30 \mathrm{mg} \mathrm{kg}^{-1}$. Alternatively, identical leaf areas per plant were obtained by non-mycorrhizal plants at a P addition of $150 \mathrm{mg} \mathrm{kg}^{-1}$; thus, 5 times more $P$ is required when the plant is not inoculated with AMF. The total leaf area per plant is often used as a growth parameter because it is strongly dependent on the photosynthetic capacity.

The leaf area per plant of mycorrhizal plants was $826 \%$ greater than that of non-mycorrhizal plants. The observed increase in the leaf area per plant was greater than that (around 500\%) observed by Carvalho (2008). Similar to the plant dry matter results of the present study, greater mycorrhizal benefit was observed at lower P levels, and the effects of mycorrhizal inoculation decreased with an increase in the P concentration. Alternatively, in the study conducted by Carvalho (2008), greater mycorrhizal benefit was obtained at high P levels, and significant differences between mycorrhizal and non-mycorrhizal plants were not observed at low $\mathrm{P}$ levels. This disparity may be due to differences in the experimental period. Namely, the experimental period of the present study was equal to 180 days, and the experiment period of the investigation conducted by Carvalho was 78 days. As a result, the maximum leaf area per plant in the present study $\left(1783 \mathrm{~cm}^{2}\right)$ was greater than that $\left(257 \mathrm{~cm}^{2}\right)$ observed by Carvalho (2008).

Leaf area characteristics are an important indicator of the plant growth rate and are often adjusted to maximize the efficiency of the use of different resources, including light and nutrients (Vendramini et al. 2002; Adams and Langton, 2005). For instance, leaf expansion leads to better light interception and enhanced rates of growth and photosynthesis, which facilitates the partitioning of dry matter in other plant organs.
The results obtained in the present study revealed that all of the variables related to the leaf area increased due to mycorrhizal inoculation. Thus, the total leaf area increased with an increase in the $\mathrm{P}$ addition due to an increase in the number of leaves and in the unit leaf. Similarly, the results of a previous study indicated that the leaf area of bean plants doubled when high soil P levels were applied due to an increase in the number of leaves and the leaf area per leaf (Trindade et al., 2010). However, mycorrhizal inoculation also had a significant effect on the number of leaves, leaf area per leaf and the leaf area ratio (LAR), which affected the total leaf area. The observed enhancement in leaf area characteristics due to AMF inoculation is in agreement with the results of previous studies. Specifically, mycorrhizal inoculation increased the leaf area and leaf area ratio (LAR) of Carica papaya by $64 \%$ and $54 \%$, respectively (Alarcón et al., 2002). Moreover, the leaf area of Leucaena leucocephala increased by $161 \%$ due to inoculation (Dixon et al., 1993). The aforementioned results confirm the effect of AMF on plant growth. One of the most pronounced effects of $P$ deficiency is a reduction in shoot growth parameters, including the number and size of leaves (Lynch et al., 1991).

The LAR expresses the total leaf area useful for photosynthesis and describes the relationship between the leaf area responsible for light and $\mathrm{CO}_{2}$ interception, and the total dry matter content (Benincasa, 2003). The LAR of physic nut plants decreased with an increase in the $\mathrm{P}$ addition, which it is in agreement with the results of Elliot and White (1993), who studied several species that compete with red pines. Non-mycorrhizal plants presented a slight decrease in the LAR as the $P$ addition increased, while the LAR of mycorrhizal plants decreased by $55 \%$ as the $\mathrm{P}$ content increased from $\mathrm{P} 0$ to P400. A lower LAR may indicate greater plant efficiency for the production of biomass.

The leaf area ratio (LAR) varies widely among species and is dependent on environmental conditions such as the supply of light and nutrients (Elliot and White, 1993). In general, the LAR decreases as the plant develop because the total phytomass content increases over time, while leaf area development decreases; thus, biomass from photoassimilation is differentially partitioned into reproductive organs.

The rate of photosynthesis in physic nut mycorrhizal plants was $30 \%$ greater than that of non-mycorrhizal plants. The beneficial effect of mycorrhizal inoculation on 
the rate of photosynthesis is in agreement with the results obtained by Carvalho (2008), who demonstrated that the rate of photosynthesis, in mycorrhizal physic nut plants was around $100 \%$ greater than that of non-mycorrhizal plants. In the aforementioned study and the current investigation, mycorrhizal inoculation had the greatest effect on the rate of photosynthesis at high $\mathrm{P}$ levels. Alternatively, in a previous study on castor beans, the rate of photosynthesis of mycorrhizal plants was $150 \%$ greater than that of nonmycorrhizal plants at low soil P levels (Machineski, 2008).

The beneficial effect of AMF on the rate of photosynthesis suggests that symbiosis may contribute to the efficiency of photosynthesis and plant growth. For instance, mycorrhizal plants often show higher photosynthetic rates than nonmycorrhizal plants (Augé, 2001). Moreover, in previous studies, mycorrhizal symbiosis also improved the rate of photosynthesis in Leucaena plants by $350 \%$ compared to nonmycorrhizal plants. When the plants were submitted to water stress conditions, the rate of photosynthesis of mycorrhizal plants was $700 \%$ greater than that of non-mycorrhizal plants (Dixon et al., 1993). The rate of photosynthesis in mycorrhizal plants is greater than that of non-mycorrhizal plants due to higher concentrations of chlorophyll (Wright et al., 1998; Machineski, 2008). According to the results presented in the literature, the rate of photosynthesis of mycorrhizal plants may be greater than that of non-mycorrhizal plants due to an increase in the number of photosynthetic units, a decrease in the internal $\mathrm{CO}_{2}$ concentration, an increase in the rate of photosynthetic storage and export, and an increase in the ratio of photosynthesis to the $\mathrm{P}$ content of the leaf (Augé, 2001). Whole-plant photosynthesis depends on the rate of photosynthesis per unit leaf area and the total leaf area per plant. Thus, the AMF has a significant effect on the photosynthetic capacity of the plant and can improve plant growth and productivity.

Mycorrhizal inoculation had a beneficial effect on physic nut plants, even when $P$ was added to the soil, which suggests that AMF can contribute to $\mathrm{P}$ absorption and transportation in the plant. The relatively high P uptake capacity of mycorrhizal plants was due to an increase in soil exploitation (more than one hundred times), which was attributed to mycorrhizal external mycelium production, higher nutrient absorption efficiency and greater affinity (lower $\mathrm{Km}$ ) for $\mathrm{P}$ uptake from the soil solution compared to normal plant roots (Smith and Read, 1997).
The greater efficiency of $P$ uptake by mycorrhizal hyphae is important because mycorrhizal plants access the same forms of available $P$ as non-mycorrhizal plants (Bolan, 1991).

The Dickson quality index (DQI) of physic nut plants increased in function of $\mathrm{P}$ addition. Mycorrhizal plants presented greater DQls than non-mycorrhizal plants at the majority of $P$ treatments as AMF inoculation improved plant growth parameters, which are related to the quality of the seedlings. The DQI is a good indicator for the quality of seedlings because it is a balanced index based on several morphological characteristics that are indicative of the robustness of the plant and the distribution of phytomass (Gomes, 2001).

The observed decrease in the relative mycorrhizal dependency (RMD) of the physic nut plant with the increase in the soil $P$ reinforce the previous data indicating that mycorrhizal inoculation had a stronger effect at low $\mathrm{P}$ levels. The negative effect of the $\mathrm{P}$ level on the RMD is in agreement with results of previous studies on mangaba trees (Hancornia speciosa) (Costa et al., 2005) and Brazilian native woody plants (Zangaro et al., 2007). However, the RMD is highly variable among plant species (Zangaro et al., 2007), AMF species and soil conditions (Nogueira and Carvalho, 2007). In a study conducted on the mangaba tree, the P level had a minor effect on the RMD; however, the RMD was strongly dependent on the mycorrhizal species (Carvalho Filho et al., 2008). In the present study, the greatest mycorrhizal efficiency was observed at low $P$ levels, which suggests that maximum mycorrhizal benefit is obtained under low $\mathrm{P}$ conditions.

The results of the present study indicate that mycorrhizal inoculation has a strong effect on physic nut plant growth, development, leaf area, P accumulation and photosynthetic rate. The effect of mycorrhizal inoculation on the production of physic nut seedlings should not be ignored because the plant presents high mycorrhizal dependency under low soil $P$ conditions. Thus, mycorrhizal inoculation may improve the development and nutrition of seedlings and promote greater transplant survival rates in the field under low soil $\mathrm{P}$ conditions.

Acknowledgements: The authors thank the Brazilian Council for Scientific and Technological Development (CNPq) and the Secretary of Paraná State for Science, Technology and Higher Education (SETI-PR) for financial support. 


\section{REFERENCES}

Adams SR, Langton FA (2005) Photoperiod and plant growth: a review. J. Hortic. Sci. Biotec. 80:2-10

Alarcón A, Davies Jr FT, Egilla JN, Fox TC, Estrada-Luna A, Ferrera-Cerrato R (2002) Short term effects of Glomus claroideum and Azospirillum brasilense on growth and root acid phosphatase activity of Carica papaya L. under phosphorus stress. Rev. Latinoam. Microbiol. 44(1):31-37.

Augé RM (2001) Water relations, drought and vesicular-arbuscular mycorrhizal symbiosis. Mycorrhiza. 11:3-42

Beltrão NEM (2005) Agronegócio das oleaginosas no Brasil. Informe Agropecuário. 26: 14-16.

Benincasa MMP (1988) Análise de crescimento de plantas. Jaboticabal: UNESP-FCAV. 41

Bolan NS (1991) A critical review on the role of mycorrhizal fungi in the uptake of phosphorus by plants. Plant and Soil. 134:189-207.

Cardoso Filho JA, Lemos EEP, Santos TMC, Caetano LC, Nogueira MA (2008) Mycorrhizal dependency of mangaba tree under increasing phosphorus levels. Pesq. Agropec. Bras. 43(7):887-892.

Carvalho AMX, (2008) Fungos micorrízicos arbusculares no crescimento de mudas de pinhão-manso. Dissertação de Mestrado, Universidade Federal de Viçosa. 48p.

Costa CMC, Cavalcante UMT, Goto BT, Santos VF, Maia LC (2005) Fungos micorrízicos arbusculares e adubação fosfatada em mudas de mangabeira. Pesq. Agropec. Bras. 40:225-232.

Dias LAS, Leme LP, Laviola BG, Pallini Filho A, Pereira OL, Carvalho M, Manfio CE, Santos AS, Sousa LCA, Oliveira TS, Dias DCFS (2007) Cultivo de pinhãomanso (Jatropha curcas L.) para produção de óleo combustível. Viçosa, MG, 40p.

Dixon RK, Rao MV, Garg VK (1993) Water relations and gas exchange of mycorrhizal Leucaena leucocephala seedlings. Trop. For. Sci. 6:542-552.

Elliott KJ, White AS (1993) Effects of competition from young northern hardwoods on red pine seedling growth, nutrient use efficiency, and leaf morphology. For. Ecol. Manage. 57:233- 255.

Gomes JM (2001) Parâmetros morfológicos na avaliação da qualidade de mudas de Eucalypyus grandis, produzidas em diferentes tamanhos de tubetes e dosagens de N-P-K. Viçosa-MG, Universidade Federal de Viçosa - Tese de doutorado.

Gomes JM, Paiva HN (2004) Viveiros florestais - propagação sexuada. $3^{\text {th }}$ ed. Viçosa: UFV.

Guimarães AA, Mendonça V, Tosta MDS, Dantas DDJ, Paula YCM, Rodrigues GSO (2010) Doses de sulfato de zinco na produção de mudas de pinheira. Rev. Bras. Ciênc. Agrár. 5(2):153-158.

Laviola BG, Dias LAS (2008) Teor e acúmulo de nutrientes em folhas e frutos de pinhão manso. Rev. Bras. Cie. Solo. 32(5):1969-1975.

Lynch J, Läuchli A, Epstein E (1991) Vegetative growth of the common bean in response to phosphorus nutrition. Crop Sci. 31:380-387.

Machineski 0 (2008) Resposta da mamoneira a fungos micorrízicos arbusculares e a doses de fósforo. Universidade Estadual de Londrina. Dissertação de Mestrado. 61p.

Marschner H, Kirkby EA, Cakmak I (1996) Effect of mineral nutritional status on shoot-root partioniting of photoassimilates and cycling of mineral nutrients. J. Exp. Bot. 47:1255-1263.
Marschner H, Dell B (1994) Nutrient uptake in mycorrhizal symbiosis. Plant and Soil. 159:89-102.

Nogueira MA, Cardoso EJBN (2007) Phosphorus availability changes the internal and external endomycorrhizal colonization and effects symbiotic effectiveness. Sci. Agric. 64:295-300.

Novais RF, Smyth TJ (1999) Fósforo em solo e planta em condições tropicais. Viçosa, MG: UFV. 399.

Núñez-Colín CA, Goytia-Jiménez MA (2009) Distribution and agroclimatic characterization of potential cultivation regions of physic nut in Mexico. Pesq. Agropec. Bras. 44(9):1078-1085.

Pavan MA, Bloch MF, Zemplski HC, Miyazawa M, Zocoler DC (1992) Manual de análise química de solo e controle de qualidade. (Circular técnica 76 ) IAPAR, Londrina.

Resende AL, Furtini Neto E, Muniz JA, Curi N, Faquin V (1999) Crescimento inicial de espécies florestais de diferentes grupos sucessionais em resposta a doses de fósforo. Pesq. Agropec. Bras. 34(11):2071-2081.

Rocha FS, Saggin Junior 0, Silva EMR, Lima WL (2006) Dependência e resposta de mudas de cedro a fungos micorrízicos arbusculares. Pesq. Agropec. Bras. 41:77-84.

Saggin Junior OJ, Siqueira JO (1996) Micorrizas arbusculares em cafeeiro. In: SIQUEIRA, J.O. (Ed.) Avanços em fundamentos e aplicação de micorrizas. Lavras: UFLA: DCS: DCF. 203-254.

Salisbury FB, Ross CW (1992) Plant physiology. 4. ed. Belmont: Wadsworth Publishing. 682p.

SAS (2002) SAS/STAT. User's guide: statistics. $9^{\text {th }}$ ed. Cary, NC, USA. SAS Institute.

Saturino HM, Pacheco DD, Kakida J, Tominaga N, Gonçalves N (2005) Cultura do Pinhão-manso (Jatropha curcas L.). Informe Agropecuário. 26(229):44-78.

Smith SE, Read DJ (1997) Mycorrhizal Symbiosis. California: Academic. Press. 506p.

Tominaga N (2007) Cultivo do pinhão manso para produção de biodiesel. Viçosa: CPT. 220p.

Trindade RS, Araújo AP, Teixeira MG (2010) Leaf area of common bean genotypes during early pod filling as related to plant adaptation to limited phosphorus supply. R. Bras. Ci. Solo. 34:115-124.

Vendramini F, Díaz S, Gurvich DE, Wilson PJ, Thompson K, Hodgson JG (2002) Leaf traits as indicators of resource-use strategy in floras with succulent species. New Phytol. 154:147-157.

Wissuwa M, Gamat G, Ismail AM (2005) Is root growth under phosphorus deficiency affected by source or sink limitations? J. Exp. Bot. 56(417):19431950.

Wright DP, Scholes JD, Read DJ (1988) Effects of VAM colonization on photosynthesis and biomass production of Trifolium repens $\mathrm{L}$. Plant. Cell. Environ. 21:209-216.

Zangaro W, Nishidate FR, Vandresen J, Andrade G, Nogueira MA (2007) Root mycorrhizal colonization and plant responsiveness are related to root plasticity soil fertility and successional status of native woody species in southern Brazil. J. Trop. Ecol. 23:53-62. 